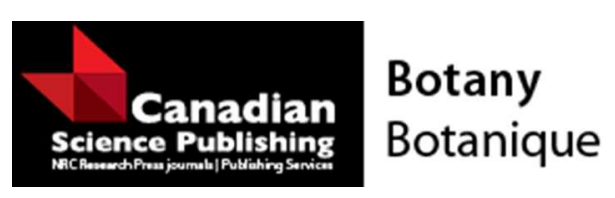

\title{
Model behavior of arbuscular mycorrhizal fungi: Predicting soil carbon dynamics under climate change
}

\begin{tabular}{|r|l|}
\hline Journal: & Botany \\
\hline Manuscript ID & cjb-2015-0245.R1 \\
\hline Manuscript Type: & Commentary \\
\hline Date Submitted by the Author: & 12-Jan-2016 \\
\hline Complete List of Authors: & $\begin{array}{l}\text { Treseder, Kathleen; University of California Irvine, Ecology and } \\
\text { Evolutionary Biology }\end{array}$ \\
\hline Keyword: & $\begin{array}{l}\text { arbuscular mycorrhizal fungi, climate change, diversity, Earth system } \\
\text { model, trait-based ecosystem model }\end{array}$ \\
\hline
\end{tabular}

SCHOLARONE ${ }^{\text {IM }}$

Manuscripts 
Model behavior of arbuscular mycorrhizal fungi: Predicting soil carbon dynamics under climate change

Kathleen K. Treseder, Dept of Ecology and Evolutionary Biology, University of California Irvine, Irvine, CA 92697 USA, treseder@uci.edu, 949-824-7634

In press, Botany 


\begin{abstract}
In this commentary, I advocate for more detailed incorporation of arbuscular mycorrhizal (AM) fungi in Earth system models, to improve our projections of global climate change. Current Earth system models display relatively low predictability of soil C stocks, which limit our ability to estimate future climate conditions. A more explicit incorporation of microbial mechanisms can increase the accuracy of ecosystem-scale models that inform the larger-scale Earth system models. Of the numerous microbial groups that can influence soil C dynamics, AM fungi are particularly tractable for integration in models. Arbuscular mycorrhizal fungi are globally abundant and perform critical roles in $\mathrm{C}$ cycling, such as augmentation of net primary productivity and soil C storage. Moreover, AM communities exhibit relatively low diversity within ecosystems, compared to other microbial groups. In addition, global datasets of AM ecology are available for use in model development. Thus, AM communities can be readily simulated in next-generation trait-based models that link microbial diversity to ecosystem function. Altogether, we are well-poised to incorporate the dynamics of individual AM taxa in ecosystem models, which can then be coupled to Earth system models. Hopefully, these efforts would advance our ability to predict and plan for future climate change.
\end{abstract}

Key words: arbuscular mycorrhizal fungi, climate change, diversity, Earth system model, soil carbon, trait-based ecosystem model 


\section{Introduction}

In the recent 2015 United Nations Climate Conference in Paris, thousands of policy makers, economists, and scientists met to negotiate global plans for mitigating and adapting to future climate change. These plans rely upon predictions of future climate provided by the International Panel on Climate Change (IPCC 2014). The predictions are developed from Earth system models. Earth system models are large-scale, integrated models that project greenhouse gas concentrations in the atmosphere. They are based on physical and biological processes that govern global carbon (C) cycling (IPCC 2014). The more accurate the model predictions are, the better-informed the climate action plans will be.

Unavoidably, Earth system models are simplified representations of complex phenomena. Accordingly, their projections have varying degrees of uncertainty, depending on how well the models portray critical processes (Randerson et al. 2009). Historically, belowground processes have been challenging to incorporate in large scale models (Todd-Brown et al. 2012). As a result, there is room for improvement in the representation of soil C dynamics in Earth system models (Tian et al. 2015). For example, Earth system models predict 0 to $39 \%$ of the current spatial variability in global soil C stocks, depending on the model (Todd-Brown et al. 2013). In turn, their predictions of global soil C stocks under future climate conditions vary widely, from a loss of $72 \mathrm{Pg}$ C to a gain of $253 \mathrm{Pg} \mathrm{C}$ (Todd-Brown et al. 2014). This level of uncertainty is a concern because soil stores more $\mathrm{C}$ globally than the atmosphere and terrestrial vegetation combined (Batjes 1996; Tarnocai et al. 2009). A proportionately small decrease in soil C stocks can lead to significant increases in atmospheric $\mathrm{CO}_{2}$ concentrations, which can feed back on future climate (Schimel et al. 1995). To better predict and offset future climate change, we need to improve the accuracy with which large-scale models simulate belowground dynamics. 
Recently, attention has turned to improving the representation of microbial ecology in Earth system models, as well as the ecosystem-scale models that inform them (e.g., McGuire and Treseder 2010; Reid 2011; Todd-Brown et al. 2012; Treseder et al. 2012; Trivedi et al. 2013; Wang et al. 2013; Xu et al. 2014). Microbes control the production or consumption of numerous greenhouse gases, including $\mathrm{CO}_{2}$ (Conrad 1996), which is important to consider when predicting future climates. Nevertheless, traditional models do not contain a great deal of microbial detail. For example, ecosystem-scale models often represent microbes as a single, uniform pool (Manzoni and Porporato 2009). Furthermore, many Earth system models do not explicitly represent microbes, although their activity is implied in the conversion of soil $\mathrm{C}$ to $\mathrm{CO}_{2}$ (ToddBrown et al. 2012). Recent large-scale models that include more microbial detail can predict soil C dynamics better (Lawrence et al. 2009; Allison et al. 2010; Allison 2012; Wieder et al. 2013; Fujita et al. 2014; Wieder et al. 2014; Powell et al. 2015; Wieder et al. 2015). Thus, microbes seem to be a promising avenue for model improvement.

However, microbes are highly diverse, both functionally and taxonomically. Recent microbially-detailed models have primarily focused on saprotrophic microbes (e.g., Allison 2012; Fujita et al. 2014; Wieder et al. 2015), with good reason. This functional group controls much of the mineralization of organic $\mathrm{C}$ and nutrients, which are critical steps in biogeochemical cycling (Chapin et al. 2011). Nevertheless, AM fungi are also worth including, owing to their abundance, roles in $\mathrm{C}$ cycling, relatively low taxonomic diversity, and availability of data for model development. I will address each of these points, and then describe approaches for modeling AM fungi. 


\section{The case for arbuscular mycorrhizal fungi}

\section{AM fungi are globally relevant}

Incorporating AM dynamics into large-scale models may improve projections of soil C storage. One reason is that they are globally abundant. Arbuscular mycorrhizal fungi form relationships with about $75 \%$ of plant species (Newman and Reddell 1987) and are present in most terrestrial ecosystems (Allen et al. 1995; Treseder and Cross 2006; Davison et al. 2015; Soudzilovskaia et al. 2015a). In fact, globally, about $45 \%$ of root length in upper soil layers is occupied by AM structures such as arbuscules, vesicles, and intraradical hyphae (Soudzilovskaia et al. 2015a). Treseder and Cross (2006) estimated that globally, about 0.5 Pg C is contained within live AM tissues inside roots in the upper $10 \mathrm{~cm}$ of soil. This amount does not include extraradical hyphae of AM fungi, or AM fungi in deeper soils, so this estimate is conservative.

\section{AM fungi influence carbon cycling}

Moreover, AM fungi control critical processes within the $\mathrm{C}$ cycle, and can mediate soil $\mathrm{C}$ storage (Rillig 2004a, b; Verbruggen et al. 2013; Mohan et al. 2014; Soudzilovskaia et al. 2015b; Verbruggen et al. 2016). For instance, they improve net primary productivity (NPP) by substantially facilitating plant uptake of $\mathrm{N}$ and $\mathrm{P}$ (Mosse 1973; Hoeksema et al. 2010). In return, they receive C from the host plant (Smith and Read 2008). Thus, a portion of the additional NPP is allocated belowground to AM fungi. In fact, AM fungi may receive about $37-47 \%$ of belowground NPP in ecosystems dominated by AM host plants (Harris et al. 1985; Harris and Paul 1987; Jakobsen and Rosendahl 1990; Johnson et al. 2002; Treseder and Cross 2006). Accordingly, the global annual flux of C into AM fungi may be substantial. As AM fungi senesce, a portion of the $\mathrm{C}$ in their biomass may remain in the soil and ultimately form soil 
organic matter (Steinberg and Rillig 2003; Rillig 2004a; Wilson et al. 2009). Altogether, AM fungi can enhance the removal of $\mathrm{CO}_{2}$ from the atmosphere by plants, and then deposit a portion of that additional $\mathrm{C}$ in the soil.

\section{Simulations of AM diversity are feasible}

In addition, AM fungi are not as phylogenetically diverse as other functional groups such as ectomycorrhizal fungi (Allen et al. 1995). In fact, AM fungi are represented by a single phylum — the Glomeromycota (Schüßler et al. 2001; Schüßler and Walker 2010). The taxonomy of AM fungi is an active area of research (Redecker et al. 2013). Currently, 260 species are described within 25 genera, 11 families, and four orders (Redecker et al. 2013, index.fungorum.org, accessed 11/2015). Undoubtedly, more species remain undescribed. "Virtual" AM can be phylogenetically defined from DNA sequences taken from environmental samples (Öpik et al. 2010). About 360 of these virtual AM taxa have been classified from global surveys (Öpik et al. 2010; Öpik et al. 2013; Davison et al. 2015). For comparison, 5000-6000 ectomycorrhizal species occupy about 250 genera across three phyla (Tedersoo and Smith 2013). Overall, AM species diversity is relatively tractable — each taxon could be individually simulated in an ecosystem model, as I will describe below.

\section{Global datasets of AM fungi are available}

Although there is much yet to learn about AM fungi, we nonetheless have a well-established foundation of knowledge about their role as plant mutualists and their responses to environmental conditions (Smith and Read 2008). Asai (1943) was the first to describe the nowclassic "big plant, little plant" experiment, in which host plants are grown with and without AM inocula to quantify AM effects on plant growth and nutrition. It has now been repeated over a 
thousand times, under numerous environmental conditions, and with a diverse array of AM and host plant species (reviewed in Koide and Mosse 2004; Hoeksema et al. 2010). A number of these experiments report that AM taxa vary in the degree to which they confer plant benefits (e.g., van der Heijden et al. 1998; Maherali and Klironomos 2007; Powell et al. 2009; Treseder 2013). Moreover, many field studies have recorded changes in AM abundance and community composition in response to elements of global change, such as elevated $\mathrm{CO}_{2}, \mathrm{~N}$ enrichment, warming, and drought (reviewed in Rillig et al. 2002; Treseder 2004; Johnson et al. 2013; Mohan et al. 2014). In addition, global distributions of AM abundance (as percent root length colonized) and AM community composition have been characterized (Tedersoo et al. 2014; Davison et al. 2015; Soudzilovskaia et al. 2015a). All this information is essential for parameterizing, validating, or benchmarking large-scale models, and much of it is compiled and publicly available (Table 1). Few microbial groups are better-characterized in this respect.

\section{Modeling arbuscular mycorrhizal fungi}

Since the $\mathrm{C}$ processes that AM fungi mediate-NPP and soil C storage-operate at the ecosystem scale, AM fungi are more readily compatible with ecosystem-scale models than with Earth system models (Talbot and Treseder 2011). This does not preclude inclusion of AM fungi in Earth system models, though. Earth system models are constructed of many submodels, including those that model processes at the land surface. State-of-the-art land surface models can represent NPP, decomposition, and other aspects of $\mathrm{C}$ and nitrogen dynamics at the ecosystem scale (e.g., Thornton et al. 2009; Gerber et al. 2010; Clark et al. 2011; Lawrence et al. 2011; Brzostek et al. 2014). These dynamics are then scaled-up to the globe within the framework of the Earth system model. Thus, AM fungi can be represented in Earth system models if they are 
included in these land surface submodels. For example, the Fixation and Uptake of Nitrogen (FUN) model is a recently-developed plant $\mathrm{N}$ model that directs plant $\mathrm{C}$ to $\mathrm{AM}$ or ectomycorrhizal fungi as a function of $\mathrm{N}$ limitation (Brzostek et al. 2014). The FUN model is already coupled to at least two land surface models: the Community Land Model (CLM, Lawrence et al. 2011) and the Joint UK Environmental Land Simulator (JULES, Clark et al. 2011). The FUN model demonstrates that it is currently feasible to include AM fungi in ecosystem models that can be scaled up to the globe.

Mycorrhizal fungi have been included in other ecosystem models such as the MYCOFON model (Meyer et al. 2010) and the Mycorrhizal Status, Carbon and Nutrient cycling model (MySCaN, Orwin et al. 2011). The MYCOFON model simulates $\mathrm{C}$ and $\mathrm{N}$ exchange between ectomycorrhizal fungi and their host plants as temperature and $\mathrm{C}$ and $\mathrm{N}$ availability varies (Meyer et al. 2010). The MySCaN model quantifies ericoid and ectomycorrhizal contributions to soil C sequestration with and without mycorrhizal uptake of organic nitrogen. These models could be applied to AM fungi as well, potentially by re-parameterizing traits like $\mathrm{C}$ demand and $\mathrm{N}$ uptake by the fungi.

We can be even more detailed in representing AM dynamics in ecosystem models, by predicting activities of specific AM taxa. This effort could increase accuracy of model predictions, because AM taxa differ in their effects on NPP and soil C dynamics as well as their responses to environmental conditions (e.g., van der Heijden et al. 1998; Maherali and Klironomos 2007; Powell et al. 2009; Chagnon et al. 2013; Johnson et al. 2013; Treseder 2013; Rillig et al. 2015). Indeed, there has been much recent interest in incorporating microbial community composition in ecosystem models, in order to improve model performance (Schimel et al. 2004; Moorhead and Sinsabaugh 2006; McGuire and Treseder 2010; Wallenstein and Hall 
2011; Crowther et al. 2014; Graham et al. 2014; Treseder and Lennon 2015). Newly-developed trait-based ecosystem models possess this capacity (Follows et al. 2007; Allison 2012; Bouskill et al. 2012; Allison 2014; Wieder et al. 2014; Wieder et al. 2015). They simulate diverse microbial communities by assigning ecological or physiological traits to individual taxa. Taxa independently respond to environmental conditions, perform ecosystem-relevant processes, and interact with each other, all based on their traits. Ecosystem functions such as soil C storage are then projected as the integration of the activities of individual taxa. Trait-based ecosystem models can outperform traditional ecosystem models when predicting $\mathrm{C}$ dynamics (Wieder et al. 2014; Wieder et al. 2015).

Trait-based ecosystem models could readily be developed for AM fungi. In fact, DEMENT, a trait-based soil C model, has already been used to simulate 200 microbial taxa simultaneously (Allison 2012). For comparison, in a recent global survey, the richness of virtual AM taxa within ecosystems ranged from 22 in a subtropical forest to 102 in a temperate grassland (Davison et al. 2015). This level of diversity is well within DEMENT's current modeling capacity.

For an AM trait-based model, AM species might be assigned traits such as $\mathrm{N}$ uptake capacity, C use efficiency, growth rate, biomass C (estimated from root colonization and hyphal length), nutrient transfer to host plants, improvements in plant growth, and environmental responses. The specific traits used would depend on the objectives and structure of the model. Suites of traits can be assigned based on trade-offs between traits (e.g., Allison 2012; Wieder et al. 2015). Few studies have explicitly examined functional trade-offs between AM traits (but see Hart and Reader 2002; Maherali and Klironomos 2007). Nevertheless, taxon-specific data on growth rate, root colonization, hyphal length, and host plant benefits are available in the literature and public datasets (Table 1). It would be valuable to synthesize these data, especially to examine 
relationships between "response" traits, which potentially influence responses of taxa to environmental conditions, and "effect" traits, which can determine effects on C cycling (sensu Lavorel and Garnier 2002). Empirically-derived relationships among these response and effect traits could be used to parameterize an AM trait-based model (sensu Allison 2012).

As with conventional ecosystem models, trait-based ecosystem models can be linked to land process models to predict soil C dynamics at the global scale (sensu Wieder et al. 2015). Likewise, an AM-focused trait model could be developed that incorporates our substantial empirical assessments of AM traits, and this model could be coupled with land surface models such as CLM. We could then generate global predictions of AM functions and community composition that can be validated against existing global AM datasets (Table 1). Moreover, we could benchmark predictions of soil C storage in comparison to conventional Earth system models (sensu Todd-Brown et al. 2013) to determine whether inclusion of AM traits increases the accuracy of the model. In the event that traits do not improve model performance, we can reassess the approach.

In conclusion, the integration of AM fungi into Earth system models via linkages with ecosystem models may improve our predictions of future climate change. Trait-based ecosystem models are an exciting new way to incorporate microbial community composition in predictions of $\mathrm{C}$ cycling, and AM fungi are a promising group to include in these early efforts, for several reasons. First, AM fungi influence global C cycling. Second, AM diversity is constrained enough to be represented in current versions of trait-based models. Third, many aspects of AM ecology are relatively well-characterized, and are available in public datasets. Ecosystem models that include AM fungi have recently been developed, and the incorporation of AM community composition in a trait-based framework is a feasible next step. If this approach indeed improves 
our predictions of atmospheric $\mathrm{CO}_{2}$ concentrations, policy makers could develop better-informed strategies for mitigating and adapting to climate change. Given the potential social, economic, and biological costs of climate change (IPCC 2014), this is a worthwhile endeavor.

\section{Acknowledgements}

I thank J. Randerson, S. Allison, P. Chagnon, and an anonymous reviewer for intellectual contributions. This project was funded by grants from NSF EAR, NSF DEB, and the U.S.

Department of Energy (Joint Genome Institute and the program in Microbial Communities and Carbon Cycling). 


\section{References}

Allen, E.B., Allen, M.F., Helm, D.J., Trappe, J.M., Molina, R., and Rincon, E. 1995. Patterns and regulation of mycorrhizal plant and fungal diversity. Plant Soil 170(1): 47-62.

Allison, S.D. 2012. A trait-based approach for modelling microbial litter decomposition. Ecol. Lett. 15: 1058-1070.

Allison, S.D. 2014. Modeling adaptation of carbon use efficiency in microbial communities. Frontiers in Microbiology 5. doi: 10.3389/fmicb.2014.00571.

Allison, S.D., Wallenstein, M.D., and Bradford, M.A. 2010. Soil-carbon response to warming dependent on microbial physiology. Nature Geoscience 3(5): 336-340.

Asai, T. 1943. The significance of mycorrhiza for plant life. Japanese Jour Bot 12: 359-436.

Batjes, N.H. 1996. Total carbon and nitrogen in the soils of the world. Eur. J. Soil Sci. 47(2): $151-163$.

Bouskill, N.J., Tang, J., Riley, W.J., and Brodie, E.L. 2012. Trait-based representation of biological nitrification: model development testing, and predicted community composition. Frontiers in Microbiology 3. doi: 10.3389/fmicb.2012.00364.

Brzostek, E.R., Fisher, J.B., and Phillips, R.P. 2014. Modeling the carbon cost of plant nitrogen acquisition: Mycorrhizal trade-offs and multipath resistance uptake improve predictions of retranslocation. Journal of Geophysical Research: Biogeosciences 119(8): 1684-1697. doi: 10.1002/2014jg002660.

Chagnon, P.L., Bradley, R.L., Maherali, H., and Klironomos, J.N. 2013. A trait-based framework to understand life history of mycorrhizal fungi. Trends Plant Sci. 18(9): 484-491. doi: 10.1016/j.tplants.2013.05.001. 
Chapin, F.S., Matson, P.A., Vitousek, P.M., and Chapin, M.C. 2011. Principles of Terrestrial Ecosystem Ecology. 2nd ed. Springer, New York.

Clark, D.B., Mercado, L.M., Sitch, S., Jones, C.D., Gedney, N., Best, M.J., Pryor, M., Rooney, G.G., Essery, R.L.H., Blyth, E., Boucher, O., Harding, R.J., Huntingford, C., and Cox, P.M. 2011. The Joint UK Land Environment Simulator (JULES), model description - Part 2: Carbon fluxes and vegetation dynamics. Geoscientific Model Development 4(3): 701-722. doi: 10.5194/gmd-4-701-2011.

Conrad, R. 1996. Soil microorganisms as controllers of atmospheric trace gases $\left(\mathrm{H}_{2}, \mathrm{CO}, \mathrm{CH}_{4}\right.$, OCS, $\mathrm{N}_{2} \mathrm{O}$, and NO). Microbiological Reviews 60(4): 609-640.

Crowther, T.W., Maynard, d.S., Crowther, T.R., Peccia, J., Smith, J.R., and Bradford, M.A. 2014. Untangling the fungal niche: A trait-based approach. Frontiers in Microbiology 5. doi: 10.3389/fmicb.2014.00579.

Davison, J., Moora, M., Öpik, M., Adholeya, A., Ainsaar, L., Bâ, A., Burla, S., Diedhiou, A.G., Hiiesalu, I., Jairus, T., Johnson, N.C., Kane, A., Koorem, K., Kochar, M., Ndiaye, C., Pärtel, M., Reier, Ü., Saks, Ü., Singh, R., Vasar, M., and Zobel, M. 2015. Global assessment of arbuscular mycorrhizal fungus diversity reveals very low endemism. Science 349(6251): 970-973. doi: 10.1126/science.aab1161.

Follows, M.J., Dutkiewicz, S., Grant, S., and Chisholm, S.W. 2007. Emergent biogeography of microbial communities in a model ocean. Science 315(5820): 1843-1846. doi: 10.1126/science. 1138544 . 
Fujita, Y., Witte, J.P.M., and van Bodegom, P.M. 2014. Incorporating microbial ecology concepts into global soil mineralization models to improve predictions of carbon and nitrogen fluxes. Global Biogeochemical Cycles 28(3): 223-238. doi: 10.1002/2013gb004595.

Gerber, S., Hedin, L.O., Oppenheimer, M., Pacala, S.W., and Shevliakova, E. 2010. Nitrogen cycling and feedbacks in a global dynamic land model. Global Biogeochemical Cycles 24. doi: $10.1029 / 2008 \mathrm{gb} 003336$.

Graham, E.B., Wieder, W.R., Leff, J.W., Weintraub, S.R., Townsend, A.R., Cleveland, C.C., Philippot, L., and Nemergut, D.R. 2014. Do we need to understand microbial communities to predict ecosystem function? A comparison of statistical models of nitrogen cycling processes. Soil Biol. Biochem. 68: 279-282. doi: 10.1016/j.soilbio.2013.08.023.

Harris, D., Pacovsky, R.S., and Paul, E.A. 1985. Carbon economy of soybean-RhizobiumGlomus associations. New Phytologist 101: 427-440.

Harris, D., and Paul, E.A. 1987. Carbon requirements of vesicular-arbuscular mycorrhizae. In Ecophysiology of VA Mycorrhizae. Edited by G.R. Safir. CRC Press, Boca Raton, Florida. pp. 93-105.

Hart, M.M., and Reader, R.J. 2002. Taxonomic basis for variation in the colonization strategy of arbuscular mycorrhizal fungi. New Phytologist 153: 335-344.

Hoeksema, J.D., Chaudhary, V.B., Gehring, C.A., Johnson, N.C., Karst, J., Koide, R.T., Pringle, A., Zabinski, C., Bever, J.D., Moore, J.C., Wilson, G.W.T., Klironomos, J.N., and Umbanhowar, J. 2010. A meta-analysis of context-dependency in plant response to inoculation with mycorrhizal fungi. Ecol. Lett. 13(3): 394-407. doi: 10.1111/j.14610248.2009.01430.x. 
IPCC. 2014. Climate Change 2013: The Physical Science Basis: Working Group I Contribution to the Fifth Assessment Report of the International Panel on Climate Change. Cambridge University Press, London.

Jakobsen, I., and Rosendahl, L. 1990. Carbon flow into soil and external hyphae from roots of mycorrhizal cucumber plants. New Phytologist 115: 77-83.

Johnson, D., Leake, J.R., Ostle, N., Ineson, P., and Read, D.J. 2002. In situ (CO $\mathrm{CO}_{2}$-C-13 pulselabelling of upland grassland demonstrates a rapid pathway of carbon flux from arbuscular mycorrhizal mycelia to the soil. New Phytologist 153(2): 327-334.

Johnson, N.C., Angelard, C., Sanders, I.R., and Kiers, E.T. 2013. Predicting community and ecosystem outcomes of mycorrhizal responses to global change. Ecol. Lett. 16: 140-153. doi: 10.1111/ele. 12085 .

Koide, R.T., and Mosse, B. 2004. A history of research on arbuscular mycorrhiza. Mycorrhiza 14(3): 145-163. doi: 10.1007/s00572-004-0307-4.

Lavorel, S., and Garnier, E. 2002. Predicting changes in community composition and ecosystem functioning from plant traits: revisiting the Holy Grail. Functional Ecology 16(5): 545-556.

Lawrence, C.R., Neff, J.C., and Schimel, J.P. 2009. Does adding microbial mechanisms of decomposition improve soil organic matter models? A comparison of four models using data from a pulsed rewetting experiment. Soil Biology and Biochemistry 41(9): 1923-1934.

Lawrence, D., Oleson, K.W., Flanner, M.G., Thorton, P.E., Swenson, S.C., Lawrence, P.J., Zeng, X., Yang, Z.-L., Levis, S., Skaguchi, K., Bonan, G.B., and Slater, A.G. 2011. Parameterization improvements and functional and structural advances in Version 4 of the 
Community Land Model. Journal of Advances in Modeling Earth Systems 3(M03001): 27 pp. doi: 10.1029/2011ms000045.

Maherali, H., and Klironomos, J.N. 2007. Influence of phylogeny on fungal community assembly and ecosystem functioning. Science 316(5832): 1746-1748. doi: 10.1126/science. 1143082 .

Manzoni, S., and Porporato, A. 2009. Soil carbon and nitrogen mineralization: Theory and models across scales. Soil Biol. Biochem. 41(7): 1355-1379. doi: 10.1016/j.soilbio.2009.02.031.

McGuire, K.L., and Treseder, K.K. 2010. Microbial communities and their relevance for ecosystem models: Decomposition as a case study. Soil Biol. Biochem. 42: 529-535.

Meyer, A., Grote, R., Polle, A., and Butterbach-Bahl, K. 2010. Simulating mycorrhiza contribution to forest C- and N cycling-the MYCOFON model. Plant Soil 327(1-2): 493-517. doi: 10.1007/s11104-009-0017-y.

Mohan, J.E., Cowden, C.C., Baas, P., Dawadi, A., Frankson, P.T., Helmick, K., Hughes, E., Khan, S., Lang, A., Machmuller, M., Taylor, M., and Witt, C.A. 2014. Mycorrhizal fungi mediation of terrestrial ecosystem responses to global change: mini-review. Fungal Ecology 10: 3-19. doi: http://dx.doi.org/10.1016/j.funeco.2014.01.005.

Moorhead, D.L., and Sinsabaugh, R.L. 2006. A theoretical model of litter decay and microbial interaction. Ecol. Monogr. 76(2): 151-174.

Mosse, B. 1973. Advances in the study of vesicular-arbuscular mycorrhiza. Annu. Rev. Phytopathol. 11: 171-196. 
Newman, E.I., and Reddell, P. 1987. The distribution of mycorrhizas among families of vascular plants. New Phytologist 106(4): 745-751.

Öpik, M., Vanatoa, A., Vanatoa, E., Moora, M., Davison, J., Kalwij, J.M., Reier, U., and Zobel, M. 2010. The online database MaarjAM reveals global and ecosystemic distribution patterns in arbuscular mycorrhizal fungi (Glomeromycota). New Phytologist 188(1): 223-241. doi: 10.1111/j.1469-8137.2010.03334.x.

Öpik, M., Zobel, M., Cantero, J.J., Davison, J., Facelli, J.M., Hiiesalu, I., Jairus, T., Kalwij, J.M., Koorem, K., Leal, M.E., Liira, J., Metsis, M., Neshataeva, V., Paal, J., Phosri, C., Polme, S., Reier, U., Saks, U., Schimann, H., Thiery, O., Vasar, M., and Moora, M. 2013. Global sampling of plant roots expands the described molecular diversity of arbuscular mycorrhizal fungi. Mycorrhiza 23(5): 411-430. doi: 10.1007/s00572-013-0482-2.

Orwin, K.H., Kirschbaum, M.U.F., St John, M.G., and Dickie, I.A. 2011. Organic nutrient uptake by mycorrhizal fungi enhances ecosystem carbon storage: a model-based assessment. Ecol. Lett. 14(5): 493-502. doi: 10.1111/j.1461-0248.2011.01611.x.

Powell, J.R., Parrent, J.L., Hart, M.M., Klironomos, J.N., Rillig, M.C., and Maherali, H. 2009. Phylogenetic trait conservatism and the evolution of functional trade-offs in arbuscular mycorrhizal fungi. Proceedings of the Royal Society B-Biological Sciences 276(1676): 42374245. doi: 10.1098/rspb.2009.1015.

Powell, J.R., Welsh, A., and Hallin, S. 2015. Microbial functional diversity enhances predictive models linking environmental parameters to ecosystem properties. Ecology 96(7): 19851993. doi: 10.1890/14-1127.1. 
Randerson, J.T., Hoffman, F.M., Thornton, P.E., Mahowald, N.M., Lindsay, K., Lee, Y.H., Nevison, C.D., Doney, S.C., Bonan, G., Stockli, R., Covey, C., Running, S.W., and Fung, I.Y. 2009. Systematic assessment of terrestrial biogeochemistry in coupled climate-carbon models. Glob. Change Biol. 15(10): 2462-2484. doi: 10.1111/j.1365-2486.2009.01912.x.

Redecker, D., Schüßler, A., Stockinger, H., Stürmer, S., Morton, J., and Walker, C. 2013. An evidence-based consensus for the classification of arbuscular mycorrhizal fungi (Glomeromycota). Mycorrhiza 23(7): 515-531. doi: 10.1007/s00572-013-0486-y.

Reid, A. 2011. Incorporating microbial processes into climate models: A report from the American Academy of Microbiology. American Academy of Microbiology, Washington DC.

Rillig, M.C. 2004a. Arbuscular mycorrhizae and terrestrial ecosystem processes. Ecol. Lett. 7(8): $740-754$.

Rillig, M.C. 2004b. Arbuscular mycorrhizae, glomalin, and soil aggregation. Canadian Journal of Soil Science 84(4): 355-363.

Rillig, M.C., Aguilar-Trigueros, C.A., Bergmann, J., Verbruggen, E., Veresoglou, S.D., and Lehmann, A. 2015. Plant root and mycorrhizal fungal traits for understanding soil aggregation. New Phytologist 205(4): 1385-1388. doi: 10.1111/nph.13045.

Rillig, M.C., Treseder, K.K., and Allen, M.F. 2002. Global change and mycorrhizal fungi. In Mycorrhizal Ecology. Edited by M. van der Heijden and I. Sanders. Springer Verlag, New York. pp. 135-160.

Schimel, D., Enting, I.G., Heimann, M., Wrigley, T.M.L., Raynaud, D., Alves, D., and Siegenthaler, U. 1995. $\mathrm{CO}_{2}$ and the carbon cycle. In Climate change 1994. Radiative forcing of climate change and an evaluation of the IPCC IS92 emission scenarios. Edited by J.T. 
Houghton and L.G. Meira Filho and J. Bruce and J. Lee and B.A. Callander and E. Haties and N. Harris and K. Maskell. Cambridge University Press, Cambridge. pp. 39-71.

Schimel, J.P., Bennett, J., and Fierer, N. 2004. Microbial community composition and soil N cycling: Is there really a connection? In 2003 Annual Symposium: Soil Biodiversity and Function. British Ecological Society, Lancaster, UK.

Schüßler, A., Schwarzott, D., and Walker, C. 2001. A new fungal phylum, the Glomeromycota: phylogeny and evolution. Mycol. Res. 105: 1413-1421.

Schüßler, A., and Walker, C. 2010. The Glomeromycota: a species list with new families and genera. The Royal Botanic Garden, Botanische Staatssammlung Munich, and Oregon State University, Edinburgh \& Kew, UK; Munich, Germany; and Oregon, USA.

Smith, S.E., and Read, D.J. 2008. Mycorrhizal Symbiosis. 3rd ed. Academic Press, San Diego.

Soudzilovskaia, N.A., Douma, J.C., Akhmetzhanova, A.A., van Bodegom, P.M., Cornwell, W.K., Moens, E.J., Treseder, K.K., Tibbett, M., Wang, Y.-P., and Cornelissen, J.H.C. 2015a. Global patterns of plant root colonization intensity by mycorrhizal fungi explained by climate and soil chemistry. Glob. Ecol. Biogeogr. 24(3): 371-382. doi: 10.1111/geb.12272.

Soudzilovskaia, N.A., van der Heijden, M.G.A., Cornelissen, J.H.C., Makarov, M.I., Onipchenko, V.G., Maslov, M.N., Akhmetzhanova, A.A., and van Bodegom, P.M. 2015b. Quantitative assessment of the differential impacts of arbuscular and ectomycorrhiza on soil carbon cycling. New Phytologist 208(1): 280-293. doi: 10.1111/nph.13447.

Steinberg, P.D., and Rillig, M.C. 2003. Differential decomposition of arbuscular mycorrhizal fungal hyphae and glomalin. Soil Biol. Biochem. 35(1): 191-194. 
Talbot, J.M., and Treseder, K.K. 2011. Ecology: Dishing the dirt on carbon cycling. Nature Clim. Change 1(3): 144-146.

Tarnocai, C., Canadell, J.G., Schuur, E.A.G., Kuhry, P., Mazhitova, G., and Zimov, S. 2009. Soil organic carbon pools in the northern circumpolar permafrost region. Global Biogeochemical Cycles 23. doi: 10.1029/2008gb003327.

Tedersoo, L., Bahram, M., Polme, S., Koljalg, U., Yorou, N.S., Wijesundera, R., Ruiz, L.V., Vasco-Palacios, A.M., Thu, P.Q., Suija, A., Smith, M.E., Sharp, C., Saluveer, E., Saitta, A., Rosas, M., Riit, T., Ratkowsky, D., Pritsch, K., Poldmaa, K., Piepenbring, M., Phosri, C., Peterson, M., Parts, K., Partel, K., Otsing, E., Nouhra, E., Njouonkou, A.L., Nilsson, R.H., Morgado, L.N., Mayor, J., May, T.W., Majuakim, L., Lodge, D.J., Lee, S.S., Larsson, K.H., Kohout, P., Hosaka, K., Hiiesalu, I., Henkel, T.W., Harend, H., Guo, L.D., Greslebin, A., Grelet, G., Geml, J., Gates, G., Dunstan, W., Dunk, C., Drenkhan, R., Dearnaley, J., De Kesel, A., Dang, T., Chen, X., Buegger, F., Brearley, F.Q., Bonito, G., Anslan, S., Abell, S., and Abarenkov, K. 2014. Global diversity and geography of soil fungi. Science 346(6213): 1078-+. doi: 10.1126/science.1256688.

Tedersoo, L., and Smith, M.E. 2013. Lineages of ectomycorrhizal fungi revisited: Foraging strategies and novel lineages revealed by sequences from belowground. Fungal Biology Reviews 27(3-4): 83-99. doi: http://dx.doi.org/10.1016/j.fbr.2013.09.001.

Thornton, P.E., Doney, S.C., Lindsay, K., Moore, J.K., Mahowald, N., Randerson, J.T., Fung, I., Lamarque, J.F., Feddema, J.J., and Lee, Y.H. 2009. Carbon-nitrogen interactions regulate climate-carbon cycle feedbacks: results from an atmosphere-ocean general circulation model. Biogeosciences 6(10): 2099-2120. 
Tian, H.Q., Lu, C.Q., Yang, J., Banger, K., Huntzinger, D.N., Schwalm, C.R., Michalak, A.M., Cook, R., Ciais, P., Hayes, D., Huang, M.Y., Ito, A., Jain, A.K., Lei, H.M., Mao, J.F., Pan, S.F., Post, W.M., Peng, S.S., Poulter, B., Ren, W., Ricciuto, D., Schaefer, K., Shi, X.Y., Tao, B., Wang, W.L., Wei, Y.X., Yang, Q.C., Zhang, B.W., and Zeng, N. 2015. Global patterns and controls of soil organic carbon dynamics as simulated by multiple terrestrial biosphere models: Current status and future directions. Global Biogeochemical Cycles 29(6): 775-792. doi: $10.1002 / 2014 \mathrm{gb005021.}$

Todd-Brown, K.E.O., Hopkins, F.M., Kivlin, S.N., Talbot, J.M., and Allison, S.D. 2012. A framework for representing microbial decomposition in coupled climate models. Biogeochemistry 109: 19-33.

Todd-Brown, K.E.O., Randerson, J.T., Hopkins, F., Arora, V., Hajima, T., Jones, C., Shevliakova, E., Tjiputra, J., Volodin, E., Wu, T., Zhang, Q., and Allison, S.D. 2014. Changes in soil organic carbon storage predicted by Earth system models during the 21st century. Biogeosciences 11(8): 2341-2356. doi: 10.5194/bg-11-2341-2014.

Todd-Brown, K.E.O., Randerson, J.T., Post, W.M., Hoffman, F.M., Tarnocai, C., Schuur, E.A.G., and Allison, S.D. 2013. Causes of variation in soil carbon simulations from CMIP5 Earth system models and comparison with observations. Biogeosciences 10(3): 1717-1736. doi: $10.5194 /$ bg-10-1717-2013.

Treseder, K.K. 2004. A meta-analysis of mycorrhizal responses to nitrogen, phosphorus, and atmospheric $\mathrm{CO}_{2}$ in field studies. New Phytologist 164(2): 347-355.

Treseder, K.K. 2013. The extent of mycorrhizal colonization of roots and its influence on plant growth and phosphorus content. Plant Soil 371: 1-13. doi: 10.1007/s11104-013-1681-5. 
Treseder, K.K., Balser, T.C., Bradford, M.A., Brodie, E.L., Dubinsky, E.A., Eviner, V.T., Hofmockel, K.S., Lennon, J.T., Levine, U.Y., MacGregor, B.J., Pett-Ridge, J., and Waldrop, M.P. 2012. Integrating microbial ecology into ecosystem models: Challenges and priorities. Biogeochemistry 109: 7-18.

Treseder, K.K., and Cross, A. 2006. Global distributions of arbuscular mycorrhizal fungi. Ecosystems 9(2): 305-316.

Treseder, K.K., and Lennon, J.T. 2015. Fungal traits that drive ecosystem dynamics on land. Microbiology and Molecular Biology Reviews 79: 243-262.

Trivedi, P., Anderson, I.C., and Singh, B.K. 2013. Microbial modulators of soil carbon storage: integrating genomic and metabolic knowledge for global prediction. Trends Microbiol. 21(12): 641-651. doi: 10.1016/j.tim.2013.09.005.

van der Heijden, M.G.A., Klironomos, J.N., Ursic, M., Moutoglis, P., Streitwolf-Engel, R., Boller, T., Wiemken, A., and Sanders, I.R. 1998. Mycorrhizal fungal diversity determines plant biodiversity, ecosystem variability and productivity. Nature 396(6706): 69-72.

Verbruggen, E., Jansa, J., Hammer, E.C., and Rillig, M.C. 2016. Do arbuscular mycorrhizal fungi stabilize litter-derived carbon in soil? J. Ecol. 104(1): 261-269. doi: 10.1111/13652745.12496.

Verbruggen, E., Veresoglou, S.D., Anderson, I.C., Caruso, T., Hammer, E.C., Kohler, J., and Rillig, M.C. 2013. Arbuscular mycorrhizal fungi - short-term liability but long-term benefits for soil carbon storage? New Phytologist 197(2): 366-368. doi: 10.1111/nph.12079. 
Wallenstein, M., and Hall, E. 2011. A trait-based framework for predicting when and where microbial adaptation to climate change will affect ecosystem functioning. Biogeochemistry: 1-13. doi: 10.1007/s10533-011-9641-8.

Walters, L., Hoeksema, J.D., Johnson, N.C., and Umbanhowar, J. 2015. MycoDB: Database for meta-analyses of mycorrhizal inoculation. hdl.handle.net/10255/dryad.10903.

Wang, G.S., Post, W.M., and Mayes, M.A. 2013. Development of microbial-enzyme-mediated decomposition model parameters through steady-state and dynamic analyses. Ecol. Appl. 23(1): 255-272.

Wieder, W.R., Bonan, G.B., and Allison, S.D. 2013. Global soil carbon projections are improved by modelling microbial processes. Nature Clim. Change 3(10): 909-912. doi: 10.1038/nclimate1951.

Wieder, W.R., Grandy, A.S., Kallenbach, C.M., and Bonan, G.B. 2014. Integrating microbial physiology and physio-chemical principles in soils with the MIcrobial-MIneral Carbon Stabilization (MIMICS) model. Biogeosciences 11(14): 3899-3917. doi: 10.5194/bg-113899-2014.

Wieder, W.R., Grandy, A.S., Kallenbach, C.M., Taylor, P.G., and Bonan, G.B. 2015. Representing life in the Earth system with soil microbial functional traits in the MIMICS model. Geoscientific Model Development 8(6): 1789-1808. doi: 10.5194/gmd-8-1789-2015.

Wilson, G.W.T., Rice, C.W., Rillig, M.C., Springer, A., and Hartnett, D.C. 2009. Soil aggregation and carbon sequestration are tightly correlated with the abundance of arbuscular mycorrhizal fungi: results from long-term field experiments. Ecol. Lett. 12(5): 452-461. doi: 10.1111/j.1461-0248.2009.01303.x. 
Xu, X.F., Schimel, J.P., Thornton, P.E., Song, X., Yuan, F.M., and Goswami, S. 2014. Substrate and environmental controls on microbial assimilation of soil organic carbon: a framework for Earth system models. Ecol. Lett. 17(5): 547-555. doi: 10.1111/ele.12254. 
Table 1. Global datasets of AM fungi that are relevant for large-scale models.

\begin{tabular}{|c|c|c|c|}
\hline Dataset & Content & URL & Reference \\
\hline AM root & Percent root length colonized by & dx.doi.org/10.1111/geb.12272 & (Soudzilovskaia et al. \\
\hline colonization & $\begin{array}{l}\text { AM fungi, projected from } \\
\text { environmental samples }\end{array}$ & & 2015a) \\
\hline $\mathrm{AM}$ root & Change in plant growth or $\mathrm{P}$ & link.springer.com/article/10.1007/s11104-013- & (Treseder 2013) \\
\hline $\begin{array}{l}\text { colonization vs } \\
\text { plant benefit }\end{array}$ & content per unit root colonization & 1681-5/fulltext.html & \\
\hline MaarjAM & $\begin{array}{l}\text { DNA sequences of virtual and } \\
\text { described AM taxa from } \\
\text { environmental samples and } \\
\text { cultures }\end{array}$ & maarjam.botany.ut.ee/ & (Öpik et al. 2010) \\
\hline MycoDB & Plant responses to AM inoculation & hdl.handle.net/10255/dryad.10903 & (Walters et al. 2015) \\
\hline
\end{tabular}

